\title{
Impact of Railroad Transport on Physical and Chemical Properties of Soils in the Railway Junction Zduńska Wola - Karsznice (Central Poland)
}

\author{
Ilona Tomczyk-Wydrych ${ }^{1 *}$ Anna Świercz ${ }^{2}$, \\ Doctoral School, Institute of Geography and Environmental Sciences, \\ Jan Kochanowski University in Kielce, Poland \\ Institute of Geography and Environmental Sciences, Jan Kochanowski University in Kielce, Poland \\ *Corresponding author: ilonatomczyk@interia.eu
}

\begin{abstract}
Railway operations and the accompanying infrastructure are responsible for the emission of pollutants and toxic substances that adversely affect both the atmospheric air, soil and the groundwater environment. The main groups include such compounds as: trace metals and aromatic hydrocarbons (PAH). Contamination of the soil and water environment with harmful substances can be associated with many activities carried out on the railway. The problem is particularly relevant to liquid fuel loading and refuelling facilities as well as to increased traffic at railway junctions.

The aim of this study was to assess heavy metal contamination of the top soil level of railway areas. The studies were conducted in the area of railway junction Zduńska Wola - Karsznice in central Poland (Łódź Voivodeship). Soil samples were collected from specific research points: from the inter-railway (A), $5 \mathrm{~m}$ from the main track (B), from the embankment - $10 \mathrm{~m}$ from the main track (C), from the side track (D), at the depth of 0-5 cm and 20 $\mathrm{cm}$. The soil samples were analysed according to laboratory methods generally accepted in soil science. The following analyses were made: granulometric composition - by sieve method, $\mathrm{pH}$ in $\mathrm{H}_{2} \mathrm{O}$ and conductivity - by potentiometric method, \% content of carbonates $\left(\mathrm{CaCO}_{3}\right)$ - by Scheibler method. Heavy metals were determined in the fractions: $0.25 \leq 0.5 \mathrm{~mm}, 0.1 \leq 0.25 \mathrm{~mm}$, and $0.05 \leq 0.1 \mathrm{~mm}$. In soil samples after mineralisation (Anton Paar Multiwave ${ }^{\mathrm{TM}} 3000$ microwave mineralizer), trace metal content was determined: $\mathrm{Pb}, \mathrm{Cd}, \mathrm{Cr}, \mathrm{Co}, \mathrm{Cu}, \mathrm{Mn}$, $\mathrm{Ni}, \mathrm{Zn}$, Sr by inductively coupled plasma mass spectrometry technique (ICP-MS/TOF OPTIMass 9500).

Based on the studied parameters, significant differentiation in soil properties of the areas in Zduńska WolaKarsznice was found. The analyses carried out showed, among others, accumulation of heavy metals $(\mathrm{Pb}, \mathrm{Cd}$, $\mathrm{Cr}, \mathrm{Co}, \mathrm{Cu}, \mathrm{Mn}, \mathrm{Ni}, \mathrm{Zn}, \mathrm{Sr}$ ) in the topsoil layer, which suggests that the source of these pollutants is mainly railway transport.
\end{abstract}

Keywords: Trace metals, Soil, Railway area

\section{Introduction}

Along with agriculture, industry, and utilities, it is transportation that contributes to a significant increase in pollution levels. Next to road transport, rail is one of the main transport means in the world. In comparison with road transport, the railroads seemed for a long time to be a relatively harmless mode of transport for the environment. This resulted in the fact that most publications were related to studies on soil contamination with heavy metals along roads and highways (Bai et al. 2009; Duong and Lee 2011; Yan et al. 2012; Zhang et al. 2015; Adamiec et al. 2016; Krailertrattanachai et al. 2019). In the last two decades, there has been a significant increase in documentation on environmental hazards and destruction associated with rail transportation (Malawska and Wiłkomirski 2001; Gehrig et al. 2007; Zhang et al. 2012; Chen et al. 2014; Wierzbicka et al. 2015; Lucas et al. 2017; Šeda et al. 2017; Stojic et al. 2017; Vaiškūnaitè and Jasiūnienè 2020; Samarska et al. 2020).

An analysis of literature reports indicates that trace metals are among the major pollutants generated in railroad areas. The specificity of these pollutants is that they are not biodegradable and decompose to simple compounds. They have the ability to bioaccumulate and biomagnify. Heavy metals emitted into the environment may migrate from soils to plants, thus there is a risk of their transport to higher trophic levels (Kabata - Pendias and Pendias 1999; Lucas et al. 2017).

The aim of this study was to assess the heavy metal contamination of the topsoil of railroad areas.

\section{Study area}

The studies on contamination of the topsoil with heavy metals were conducted in the area of railroad junction Zduńska Wola-Karsznice in central Poland (Lódź Voivodeship) (Fig. 1). According to physico- 
geographical division by Kondracki (2002) the area is situated in the south Wielkopolska Lowland macroregion and Łaska Upland mesoregion. The largest part of this area, included in the Łaska Upland, is covered by boulder clays, sands and gravels of glacial accumulation of the Central Poland glaciation.

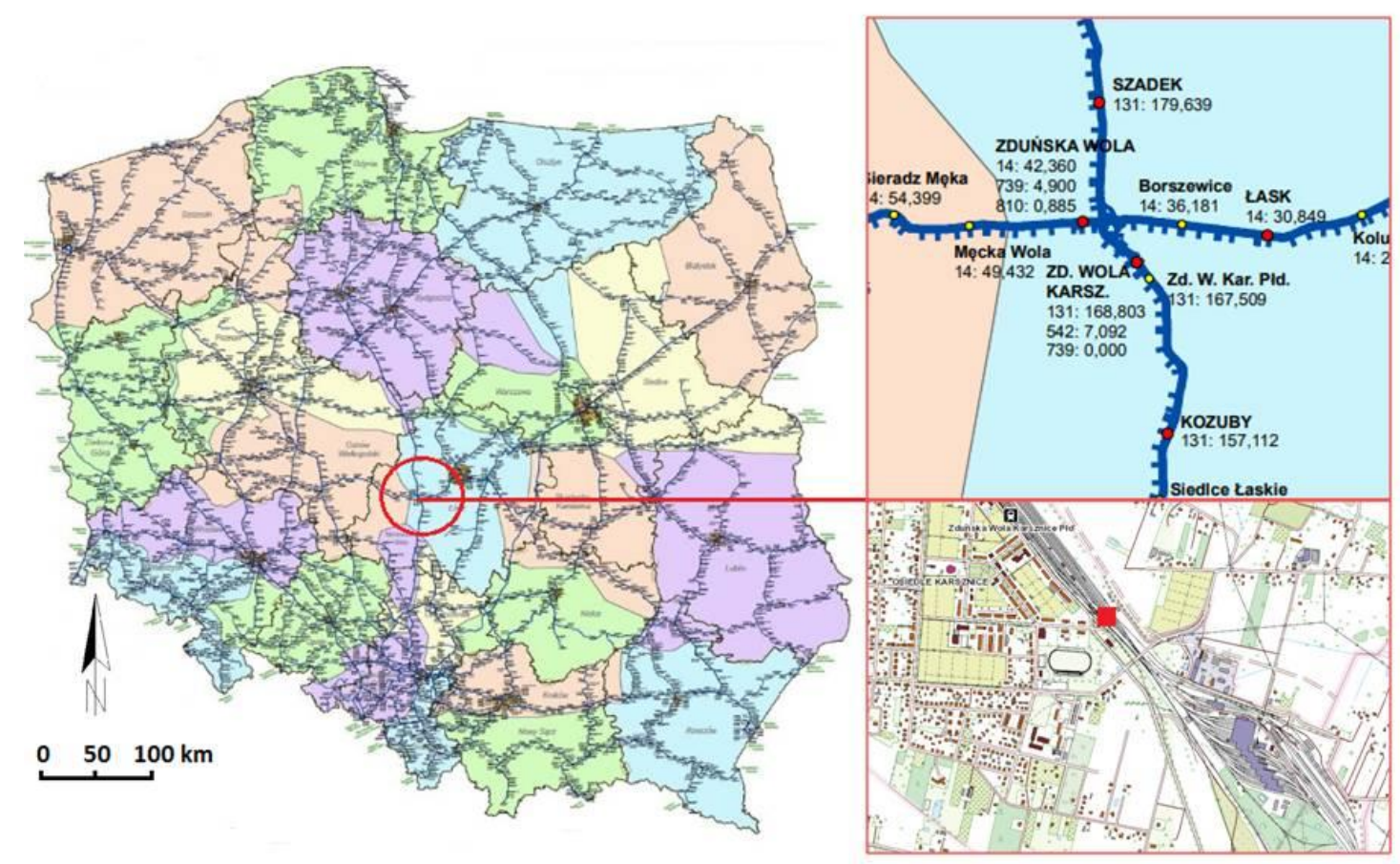

Fig. 1 Administrative location of the study area (http://mapa.plk-sa.pl/).

The railroad junction in Zduńska Wola functions as a junction for freight trains travelling in the direction Wroclaw - Silesia - Central Poland. It is located in the south-eastern part of the town (N 51 '34'35.47', E 1900'36.74”), $187 \mathrm{~m}$ above sea level (Fig. 1). The $2.6 \mathrm{~m}$ wide railroad sleeper (inter-railway width $1.6 \mathrm{~m}$ ) is made of treated wood. The distance from the second main track is $2.5 \mathrm{~m}$, while the distance from the side track is $7 \mathrm{~m}$.

\section{Methodology}

Soil samples for the study were collected from four locations: inter-railway (A) $-5 \mathrm{~m}$ from the main track, (B) - from the embankment - $10 \mathrm{~m}$ from the main track, (C) - from the side track (D). Mineral samples were collected from two depths: $0-5 \mathrm{~cm}$ and $20 \mathrm{~cm}$ (Table 1).

Table 1. Sampling location.

\begin{tabular}{cl}
\hline Designation & Sampling site \\
\hline A & inter-railway, depth $20 \mathrm{~cm}$ \\
B1 & 5 m from the main track, depth $0-5 \mathrm{~cm}$ \\
B2 & 5 m from the main track, depth $20 \mathrm{~cm}$ \\
C1 & embankment, 10 meters from the main track, depth $0-5 \mathrm{~cm}$ \\
C2 & embankment, 10 meters from the main track, depth $20 \mathrm{~cm}$ \\
D & side track, depth $20 \mathrm{~cm}$ \\
\hline
\end{tabular}

The obtained soil material, after drying to an air-dry state, was analysed in the Environmental Research Laboratory of the Department of Environmental Protection and Management, Jan Kochanowski University in Kielce.

The analysis of soil samples was conducted using generally accepted methods in soil science: granulometric composition - by sieve method, $\mathrm{pH}$ in $\mathrm{H}_{2} \mathrm{O}$ and conductivity - by potentiometric method, \% carbonate content $\left(\mathrm{CaCO}_{3}\right)$ - by Scheibler method (Bednarek et al. 2004). Heavy metal determination was 
carried out in the fraction of $0.25 \leq 0.5 \mathrm{~mm}$ (medium sand), $0.1 \leq 0.25 \mathrm{~mm}$ (fine sand) and $0.05 \leq 0.1 \mathrm{~mm}$ (very fine sand) (according to PTG 2008). For this purpose, soil samples were dissolved in a mixture of $\mathrm{HNO}_{3}$ and $\mathrm{HCl}$ acids (1:3) and mineralized in an Anton Paar Multiwave TM 3000 mineralizer. The samples were rinsed with deionized water and the contents of heavy metals $\mathrm{Pb}, \mathrm{Cd}, \mathrm{Cr}, \mathrm{Co}, \mathrm{Cu}, \mathrm{Mn}, \mathrm{Ni}, \mathrm{Zn}$, Sr were determined in the filtrate using an ICP-MS/TOF OPTIMass 9500 plasma mass spectrometer. Statistical analysis of the data was conducted using Microsoft Office Excel software. Based on the mean geochemical background values developed by Czarnowska (1996), the heavy metal accumulation index (Wn) in the soil was calculated, i.e. the quotient of determined geometric mean content of individual metals and the content in source rocks.

\section{Results}

The granulometric analysis showed that the grain size composition of investigated samples varied from one test point to another. Most of the samples showed enrichment in skeletal parts.

The $\mathrm{pH}$ values in $\mathrm{H}_{2} \mathrm{O}$ ranged from 6.47 (slightly acidic) to 7.29 (slightly basic). The lowest values were found in samples collected from the embankment located $10 \mathrm{~m}$ from the main track (6.63-6.46). The highest values were found in soils collected from the side track (7.16-7.29) and the inter-railway (6.8-7.01). The coarse sand fraction $(0.5 \leq 1.0)$ and the very fine sand fraction $(0.05 \leq 0.1 \mathrm{~mm})$ had the highest mean $\mathrm{pH}$ values $(6.84)$ while the fine sand fraction $(0.1 \leq 0.25 \mathrm{~mm})$ had the lowest mean $\mathrm{pH}$ value (6.78) (Fig. 2$)$.

In the soils of studied railroad junction, the fraction of very coarse sand $(1.0 \leq 2.0 \mathrm{~mm})$ had the highest $\mathrm{CaCO}_{3}$ content $(3.89 \%)$ and the fraction of very fine sand $(0.05 \leq 0.1 \mathrm{~mm}) 3.97 \%$, while the fraction of medium sand $(0.25 \leq 0.5 \mathrm{~mm}) 0.25 \%$ and coarse sand $(0.5 \leq 1.0 \mathrm{~mm})(0.25 \%)$ had the lowest content (Fig. 2$)$.

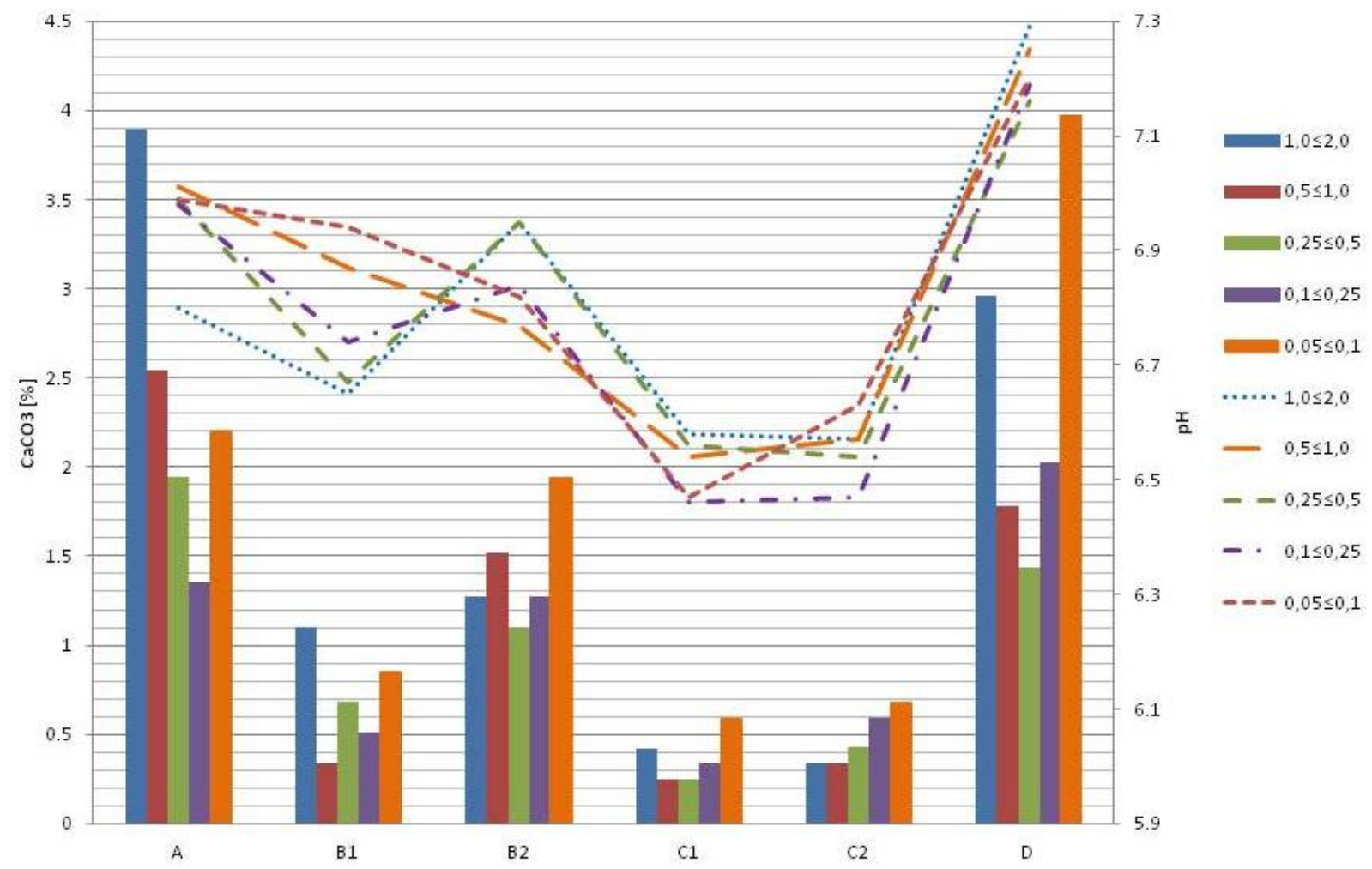

Figure 2. $\mathrm{CaCO}_{3}$ content $(\%)$ and $\mathrm{pH}$ value in different fractions $(1.0 \leq 2.0 ; 0.5 \leq 1.0 ; 0.25 \leq 0.5 ; 0.1 \leq 0.25 ; 0.05 \leq 0.1$ $\mathrm{mm}$ ) depending on the sampling location. Designations: A (inter-railway, depth $20 \mathrm{~cm}), \mathrm{B} 1(5 \mathrm{~m}$ from the main track, depth 0-5 cm), B2 (5 m from the main track, depth $20 \mathrm{~cm}), \mathrm{C} 1(5 \mathrm{~m}$ from the main track, depth $20 \mathrm{~cm}), \mathrm{C} 2$ (embankment, 10 meters from the main track, depth $20 \mathrm{~cm}$ ), D (side track, depth $20 \mathrm{~cm}$ ).

The average conductivity value of topsoil samples was $205.34 \mu \mathrm{S} \cdot \mathrm{cm}^{-1}$, the lowest $-116.4 \mu \mathrm{S} \cdot \mathrm{cm}^{-1}$ was found in the coarse sand fraction $0.5 \leq 1.0 \mathrm{~mm}$ (embankment, $10 \mathrm{~m}$ from the main track), the highest with a value of $460 \mu \mathrm{S} \cdot \mathrm{cm}^{-1}$ concerned samples collected from the side track (fraction in the range: $0.05 \leq 0.1 \mathrm{~mm}$ ). 
Table 2. Heavy metal content ( $\mathrm{mg} \cdot \mathrm{kg}^{-1}$ d.w.) according to sampling location A (inter-railway, depth $\left.20 \mathrm{~cm}\right), \mathrm{B} 1$ ( $5 \mathrm{~m}$ from the main track, depth $0-5 \mathrm{~cm}), \mathrm{B} 2(5 \mathrm{~m}$ from the main track, depth $20 \mathrm{~cm}), \mathrm{C} 1(5 \mathrm{~m}$ from the main track, depth $20 \mathrm{~cm}$ ), C2 (embankment, 10 meters from the main track, depth $20 \mathrm{~cm}$ ), D (side track, depth $20 \mathrm{~cm}$ ) and fraction diameter $(0.05 \leq 0.1 \mathrm{~mm} ; 0.1 \leq 0.25 \mathrm{~mm} ; 0.25 \leq 0.5 \mathrm{~mm})$.

\begin{tabular}{|c|c|c|c|c|c|c|c|c|c|c|c|}
\hline \multirow{2}{*}{$\begin{array}{c}\text { Sampling } \\
\text { location }\end{array}$} & \multirow{2}{*}{$\begin{array}{c}\text { Depth } \\
{[\mathrm{cm}]}\end{array}$} & \multirow{2}{*}{$\begin{array}{c}\text { Fraction } \\
{[\mathrm{mm}]}\end{array}$} & $\mathbf{P b}$ & Cd & $\mathrm{Cr}$ & Co & $\mathbf{C u}$ & Mn & $\mathbf{N i}$ & $\mathbf{Z n}$ & $\mathrm{Sr}$ \\
\hline & & & \multicolumn{9}{|c|}{$\mathrm{mg} \cdot \mathrm{kg}^{-1}$ d.w. } \\
\hline \multirow[t]{3}{*}{$\mathbf{A}$} & 20 & $0.05 \leq 0.1$ & 111.1 & 0.5 & 71.8 & 7.6 & 1371.9 & 1848.5 & 38.1 & 460.6 & 115.5 \\
\hline & 20 & $0.1 \leq 0.25$ & 63.4 & 0.5 & 41.4 & 4.1 & 636.4 & 1065.5 & 22.7 & 219.8 & 167.0 \\
\hline & 20 & $0.25 \leq 0.5$ & 22.3 & 0.2 & 21.9 & 2.1 & 379.4 & 986.5 & 13.2 & 121.4 & 61.5 \\
\hline \multirow[t]{3}{*}{ B1 } & $0-5$ & $0.05 \leq 0.1$ & 60.0 & 0.2 & 12.1 & 2.0 & 127.2 & 649.9 & 10.3 & 180.7 & 44.2 \\
\hline & $0-5$ & $0.1 \leq 0.25$ & 30.1 & 0.1 & 6.1 & 1.2 & 70.5 & 409.3 & 6.3 & 101.4 & 50.5 \\
\hline & $0-5$ & $0.25 \leq 0.5$ & 16.4 & 0.0 & 3.0 & 0.0 & 65.3 & 343.9 & 0.0 & 66.9 & 18.1 \\
\hline \multirow[t]{3}{*}{ B2 } & 20 & $0.05 \leq 0.1$ & 174.6 & 0.4 & 10.1 & 5.2 & 161.9 & 958.7 & 24.8 & 370.8 & 120.7 \\
\hline & 20 & $0.1 \leq 0.25$ & 41.9 & 0.0 & 6.4 & 0.0 & 65.7 & 540.1 & 6.3 & 132.0 & 86.3 \\
\hline & 20 & $0.25 \leq 0.5$ & 57.4 & 0.2 & 6.3 & 2.4 & 80.8 & 638.9 & 12.7 & 147.3 & 71.8 \\
\hline \multirow[t]{3}{*}{$\mathrm{C1}$} & $0-5$ & $0.05 \leq 0.1$ & 168.1 & 0.2 & 9.0 & 2.1 & 178.9 & 602.7 & 11.2 & 142.7 & 75.5 \\
\hline & $0-5$ & $0.1 \leq 0.25$ & 144.1 & 0.3 & 7.4 & 1.6 & 94.9 & 414.5 & 7.5 & 80.9 & 71.4 \\
\hline & $0-5$ & $0.25 \leq 0.5$ & 47.4 & 0.1 & 3.4 & 1.0 & 47.0 & 282.8 & 4.5 & 41.3 & 32.0 \\
\hline \multirow[t]{3}{*}{$\mathrm{C2}$} & 20 & $0.05 \leq 0.1$ & 63.0 & 0.2 & 8.1 & 10.4 & 76.1 & 1218.8 & 39.4 & 98.0 & 203.8 \\
\hline & 20 & $0.1 \leq 0.25$ & 30.0 & 0.1 & 6.8 & 7.1 & 50.8 & 891.3 & 29.2 & 70.4 & 227.7 \\
\hline & 20 & $0.25 \leq 0.5$ & 12.4 & 0.2 & 7.5 & 5.4 & 31.0 & 721.0 & 22.2 & 34.7 & 195.1 \\
\hline \multirow[t]{3}{*}{ D } & 20 & $0.05 \leq 0.1$ & 68.0 & 0.2 & 20.3 & 2.1 & 270.5 & 1601.5 & 12.5 & 189.8 & 92.7 \\
\hline & 20 & $0.1 \leq 0.25$ & 19.9 & 0.1 & 8.3 & 1.1 & 76.4 & 1090.4 & 6.3 & 73.2 & 76.9 \\
\hline & 20 & $0.25 \leq 0.5$ & 33.7 & 0.1 & 10.1 & 1.2 & 103.3 & 1254.3 & 6.1 & 101.5 & 49.2 \\
\hline
\end{tabular}

The study shows that the highest concentrations of elements occurred in samples from the inter-railway (A) and the side track (D). An increase in pollutant concentrations was observed in the embankment $10 \mathrm{~m}$ from the track $(\mathrm{C})$, which may be due to the close proximity to the road. The lowest element concentrations were recorded $5 \mathrm{~m}$ from the main track (B).

The average concentration of $\mathrm{Pb}$ was $64.6 \mathrm{mg} \cdot \mathrm{kg}^{-1}$ d.w. $\left(12.4-174.6 \mathrm{mg} \cdot \mathrm{kg}^{-1}\right.$ d.w.). The highest $\mathrm{Pb}$ concentrations were found in samples A, B2 and C1, while the lowest concentrations were found in $\mathrm{C} 2$. The highest concentration of $\mathrm{Cd}$ was found in samples $\mathrm{A}\left(0.5 \mathrm{mg} \cdot \mathrm{kg}^{-1} \mathrm{~d} . \mathrm{w}\right.$.), with no Cd recorded in B1 and B2 (0 $\mathrm{mg} \cdot \mathrm{kg}^{-1}$ d.w.). Higher cadmium values were found in $0.05 \leq 0.1 \mathrm{~mm}$ fraction. The mean $\mathrm{Cr}$ concentration was equal to $14.5 \mathrm{mg} \cdot \mathrm{kg}^{-1}$ d.w., the maximum, $71.8 \mathrm{mg} \cdot \mathrm{kg}^{-1} \mathrm{~d}$.w., was recorded in samples A, while the minimum was $3.0 \mathrm{mg} \cdot \mathrm{kg}^{-1} \mathrm{~d}$.w. in B1. The Co content ranged from $0(\mathrm{~B} 1, \mathrm{~B} 2)$ to $10.4 \mathrm{mg} \cdot \mathrm{kg}^{-1} \mathrm{~d} . \mathrm{w}$. (C2). Concentrations were comparatively low at the other sites. In the topsoil, the mean copper content was $216.2 \mathrm{mg} \cdot \mathrm{kg}^{-1} \mathrm{~d}$.w., the maximum $1371.9 \mathrm{mg} \cdot \mathrm{kg}^{-1} \mathrm{~d} . \mathrm{w}$. (A), while the minimum was $31.0 \mathrm{mg} \cdot \mathrm{kg}^{-1} \mathrm{~d} . \mathrm{w}$. (C2). The highest concentrations of $\mathrm{Cu}$ were recorded in the inter-railway, and the values decreased with distance from the track. The study shows that the average $\mathrm{Mn}$ content was $862.1 \mathrm{mg} \cdot \mathrm{kg}^{-1} \mathrm{~d} . \mathrm{w}$., with minimum $282.8 \mathrm{mg} \cdot \mathrm{kg}^{-1} \mathrm{~d} . \mathrm{w}$. (C1), and minimum $1848.5 \mathrm{mg} \cdot \mathrm{kg}^{-1}$ d.w. (A). High concentrations were also recorded in samples D. For manganese, there was a correlation between concentration and depth.At a depth of $20 \mathrm{~cm}$, higher $\mathrm{Mn}$ contents were recorded than in samples from the $0-5 \mathrm{~cm}$ level. The mean Ni concentration was equal to $15.2 \mathrm{mg} \cdot \mathrm{kg}^{-1} \mathrm{~d}$.w., with a maximum of $39.4 \mathrm{mg} \cdot \mathrm{kg}^{-1}$ d.w., recorded in $\mathrm{C} 2$ and was most likely due to proximity to the road. A similar value to the maximum equal to $38.1 \mathrm{mg} \cdot \mathrm{kg}^{-1} \mathrm{~d}$.w. was also recorded in $\mathrm{A}$, while no $\mathrm{Ni}$ was found in $\mathrm{B} 1 \mathrm{samples}$. The mean $\mathrm{Zn}$ content was $146.3 \mathrm{mg} \cdot \mathrm{kg}^{-1} \mathrm{~d}$.w. with highly significant variation in results between sites. The minimum and maximum values were $34.7 \mathrm{mg} \cdot \mathrm{kg}^{-1} \mathrm{~d} . \mathrm{w}$. and $460.6 \mathrm{mg} \cdot \mathrm{kg}^{-1} \mathrm{~d} . \mathrm{w}$., respectively. The highest concentration of zinc in the substrate was found in samples A as well as B1 and B2. The Sr content ranged from 18.1 (B1) to 227,.7 $\mathrm{mg} \cdot \mathrm{kg}^{-1} \mathrm{~d}$.w. (C2), with a mean of $97.8 \mathrm{mg} \cdot \mathrm{kg}^{-1} \mathrm{~d}$.w. High concentrations were also recorded in the inter-railway (167.0 $\mathrm{mg} \cdot \mathrm{kg}^{-1}$ d.w.) (Fig. 3). 


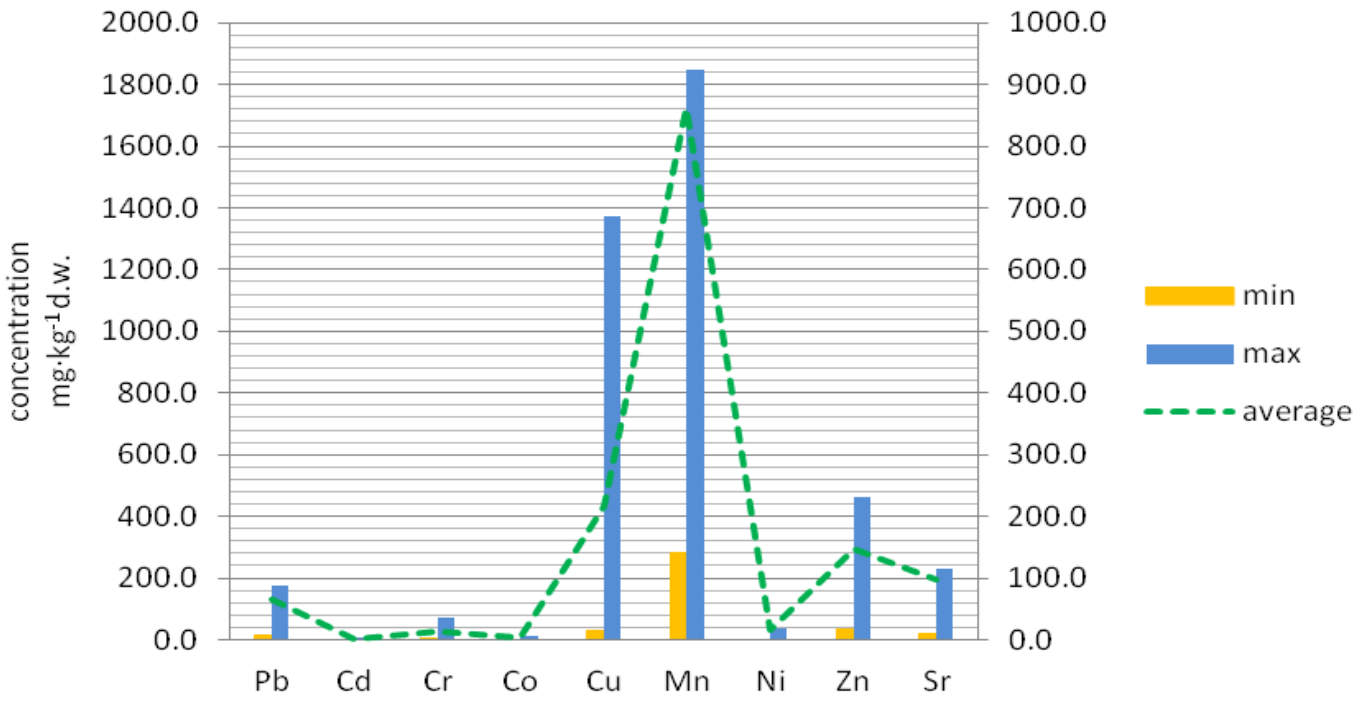

Figure 3. Ranges of metals tested in soil samples.

Based on the mean geochemical background values developed by Czarnowska (1996), an index of heavy metal accumulation (Wn) in the soil was calculated (Table 3).

Table 3. Heavy metal accumulation index in soil samples.

\begin{tabular}{|c|c|c|c|c|c|c|c|c|}
\hline \multirow[t]{2}{*}{ Sampling location } & \multicolumn{8}{|c|}{ Index of heavy metal accumulation } \\
\hline & $\mathbf{P b}$ & $\mathbf{C d}$ & $\mathbf{C r}$ & Co & $\mathbf{C u}$ & Mn & $\mathbf{N i}$ & Zn \\
\hline Inter-railway & 6.7 & 22.2 & 1.7 & 1.1 & 112.1 & 4.5 & 2.4 & 8.9 \\
\hline $5 \mathrm{~m}$ from the main track & 6.5 & 5.5 & 0.3 & 0.4 & 13.4 & 2.0 & 1.0 & 5.5 \\
\hline 10 meters from the main track & 7.9 & 11.1 & 0.3 & 1.1 & 11.2 & 2.4 & 1.9 & 2.6 \\
\hline Side track & 4.1 & 5.5 & 0.5 & 0.4 & 21.3 & 4.5 & 0.8 & 4.0 \\
\hline
\end{tabular}

The accumulation index values for $\mathrm{Pb}, \mathrm{Cd}, \mathrm{Cr}, \mathrm{Co}, \mathrm{Cu}, \mathrm{Mn}, \mathrm{Ni}, \mathrm{Zn}$ ranged from 0.3 (for $\mathrm{Cr}$ ) to 112.1 (for $\mathrm{Cu}$ ). It should be noted that the highest accumulation index values of $\mathrm{Wn}=22.2$ for cadmium; $\mathrm{Wn}=1.7$ for chromium; $\mathrm{Wn}=1.1$ for cobalt; $\mathrm{Wn}=112.1$ for copper; $\mathrm{Wn}=4.5$ for manganese; $\mathrm{Wn}=2.4$ for nickel and $\mathrm{Wn}=8.9$ for zinc were found in the samples from the inter-railway, while the highest accumulation index of $\mathrm{Wn}=7.9$ for lead was found in the samples collected $10 \mathrm{~m}$ from the track. The mean accumulation index values in the investigated soils were arranged in the following series $\mathrm{Cu}>\mathrm{Cd}>\mathrm{Pb}>\mathrm{Zn}>\mathrm{Mn}>\mathrm{Ni}>\mathrm{Co}>\mathrm{Cr}$.

\section{Discussion of results}

The topsoil levels in the railroad areas in Zduńska Wola are contaminated with lead, cadmium, chromium, cobalt, copper, manganese, nickel, zinc and strontium. Similar conclusions are found in foreign papers e.g. Liu et al. 2009; Chen et al. 2014; Zhang et al. 2012; Zhang et al. 2015; Lucas et al. 2017; Šeda et al. 2017; Stojic et al. 2017; Vaiškūnaitè and Jasiūnienè 2020; Samarska et al. 2020) and in Poland (Malawska et al. 2001; Wiłkomirski et al. 2011; Wiłkomirski et al. 2012; Jóźwiak et al. 2013). Contaminants accumulate in the near-surface soil horizon.

According to Kabata-Pendias et al. (1999), the limiting content of heavy metals in soils containing only anthropogenic pollutants is for $\mathrm{Cd} 1, \mathrm{Cu} 25, \mathrm{Ni} \mathrm{50,} \mathrm{Pb} 70, \mathrm{Cr} 100, \mathrm{Zn} \mathrm{150,} \mathrm{Mn} 1000 \mathrm{mg} \cdot \mathrm{kg}^{-1}$. Comparing the obtained results with the limiting values of heavy metals accumulated in anthropogenic soils according to 
Kabata-Pendias et al. (1999), it was established that mean concentrations of heavy metals in samples from Zduńska Wola were exceeded for $\mathrm{Cu}$ (at each sampling point), $\mathrm{Mn}$ (inter-railway, side track), $\mathrm{Zn}$ (inter-railway, $5 \mathrm{~m}$ from the track) and $\mathrm{Pb}(10 \mathrm{~m}$ from the track).

In the operational sphere, trains are susceptible to destructive environmental influences (i.e. atmospheric factors causing corrosion and damage due to lightning, ultraviolet radiation and temperature changes; human activity). All of these factors contribute to the formation of specific wastes that lead to soil contamination. These include e.g. damaged and worn out elements of the vehicle, polluting substances accumulated on the vehicle, waste created in the process of disinfecting compartments, toilets and in the process of heating, ventilating, cleaning, used technical liquids (oils, greases, hydraulic liquids) and in case of freight cars - the remains of transported loads (e.g. wood, cement, coal, liquid chemical products), sludge from domestic and sanitary wastewater (organic and inorganic particles, detergents, soaps, paper, disinfectants, faecal matter) and vapours of solvents, sulphuric and oxalic acid emitted into the atmosphere.Generally, the waste contains steel (Fe, C), nonferrous metals ( $\mathrm{Al}, \mathrm{Mg}, \mathrm{Ti}, \mathrm{Cu}, \mathrm{Zn}, \mathrm{Ni}, \mathrm{Pb}, \mathrm{Cd}$ ), rubber, plastics, chemicals, and glass. Oil and hydraulic fluids leaking from shock absorbers, discs, buffer bushings, draw hook guides and grease $(\mathrm{Ca}, \mathrm{Cu}, \mathrm{Al}, \mathrm{Li})$ found on the current collectors of electric locomotives pulling wagons also contribute to soil pollution (Malawska et al. 2001; Moczarski 2006; Liu et al. 2009; Wiłkomirski 2010; Wiłkomirski et al. 2011; Jóźwiak et al. 2013). Antuniassi et al. (2004) also showed that herbicides used for conservation purposes on railroad lands contribute to soil degradation.

According to Chillrud et al. (2005) and Moczarski (2006), iron oxides, which are formed from oxidized cast iron brake blocks, wheelset rims, brake discs, and from corroded fragments of railroad cars, and copper oxides formed from oxidized power collectors and catenary lines are among the compounds that cause soil contamination (Chillrud et al. 2005; Moczarski 2006). This thesis is supported by the present study. The highest concentration of $\mathrm{Cu}$ was detected in the area of rails. According to Wiłkomirski et al. (2012), this is a result of intensive operation of pantographs by rail vehicles, which are used to collect current from the overhead catenary wires.

Analyzing the study of Samarska et al. (2020), the Fe content in soil samples from railroad areas was strongly correlated with $\mathrm{Ni}, \mathrm{Cr}$ and $\mathrm{Mn}$ content. The values of element concentrations in the studied soils were arranged in the following order: $\mathrm{Fe}>\mathrm{Mn}>\mathrm{Cu}>\mathrm{Cr}>\mathrm{Ni}>\mathrm{Zn}>\mathrm{Pb}>$ As. These metals are components of railroad steel, as noted by Samarska et al. (2020), and may be derived from rail and wheel abrasion.

According to Liu et al. (2009), the Mn comes from wheel and rail abrasion, while $\mathrm{Pb}$ and $\mathrm{Cd}$ from automobile emissions. Therefore, the authors claim that the abrasion of train bodies and the discarding of waste by travelers can be a source of heavy metals in the soils of railroad areas. Similar observations were made by Vaiškūnaitè \& Jasiūnienè (2020), who found that the highest concentrations of $\mathrm{Pb}$ and Cd were recorded at a distance of $5.0 \mathrm{~m}$ from railroad sleepers in the upper (up to $10 \mathrm{~cm}$ ) layer of soil.

The study of Łukasiewicz (2011), showed that lead was present in the upper part of the profile at 6 of 21 sites, while deeper at 19 sites already. This is not consistent with the results presented in the paper. The study does not support the thesis that $\mathrm{Pb}$ concentration increases with the depth of soil profile.

Cadmium was characterized by the lowest concentration in the studied soil samples. Concentration of this element does not show any change depending on the depth of sampling. It is accumulated both in shallower and deeper soil profiles. The investigated soil samples contain high concentrations of manganese, which sorbs cadmium, thus decreasing its mobility in the environment and availability to the flora. The content of $\mathrm{Mn}$ and $\mathrm{Zn}$ does not show a strong correlation with the depth of sampling, which confirms that $\mathrm{Mn}$ and $\mathrm{Zn}$ are common elements and their content in soil strongly depends on the content in the source rock (Rapalska 2010). While, the presence of lead is largely the result of anthropogenic activity rather than the result of source rock. Liu et al. (2009) argue that high organic matter content may contribute to heavy metal retention in the immediate vicinity of railroad areas.

The effect of a busy railroad line in Zurich on the amount of heavy metal emissions was the subject of Bukowiecki et al. (2007). The results clearly show that more than half of the iron and manganese from wheel and rail abrasion are particles of size $2.5-10 \mathrm{~mm}$.

The study conducted by Liu et al. (2009) in China shows that heavy metals, the emission of which is particularly associated with rail transport, are zinc, copper and manganese that is consistent with the observations conducted in Zduńska Wola. As noted by Stojic et al. 2017, the concentration values of $\mathrm{Cu}, \mathrm{Ni}, \mathrm{Cd}, \mathrm{Pb}$ in samples collected from up to $1 \mathrm{~km}$ from the railroad line were higher than in samples collected from $>1 \mathrm{~km}$, which is consistent with the research conducted in Zduńska Wola.

Chen et al. (2014) conducted a study near Suining railroad station, Sichuan province, China. They sampled a newly constructed railroad line and lines in operation for 5, 9, and 15 years. According to Chen et al. (2014), the concentration levels of $\mathrm{Zn}, \mathrm{Cu}$ and $\mathrm{Fe}$ in soil samples are not affected by anthropogenic activities, soils were contaminated with $\mathrm{Cd}$ and $\mathrm{Pb}$, and their maximum content was determined in samples from railroad areas with the longest operating time. Similar conclusions were drawn by Chen et al. (2014) concluding that lead 
and cadmium in soils from railroad sites mainly comes from anthropogenic activities i.e., leaks from railcars and dust emissions from transported materials. As noted by Chen et al. (2014), the level of $\mathrm{Cd}$ and $\mathrm{Pb}$ contamination decreased along with increasing distance from the rail. Similar findings are presented in this paper, with Cd and $\mathrm{Pb}$ contamination levels again increasing in samples collected along the community road. A good sampling practice was followed by Zhang et al. (2015), who conducted a study on the world's highest railroad line Qinghai-Tibet. To avoid any influences from the highway, samples were collected from a railroad track located away from the highway. The authors found that the concentrations of $\mathrm{V}, \mathrm{Co}$ and $\mathrm{Rb}$ were the same in each sample, while the values of $\mathrm{Zn}, \mathrm{Cd}$ and $\mathrm{Cd}$ in the samples from the embankment were seven times higher than the geochemical background of study area. Zhang et al. (2012) and Zhang et al. (2015), also observed that landform is the most probable cause of differences in the concentrations of heavy metals such as $\mathrm{Pb}, \mathrm{Zn}$ and $\mathrm{Cd}$.

Studies conducted by Malawska et al. (2000) on railroad areas in Tarnowskie Góry show that the level of heavy metal contamination near railroad sites decreased with increasing distance from the rails, which is consistent with the results presented in this paper. Malawska et al. (2001) also state that transport of goods, which contain harmful water-soluble substances, contributes to soil contamination in railroad areas. This is even more dangerous in the case of trains that remain in one place for a long time.

Malawska et al. (2001) and Wiłkomirski et al. (2012) in their papers determining the content of heavy metals in soil and plant samples collected from railroad sites (Iława Główna) concluded that railroad transport can be a significant threat to the environment. This refers to both organic and inorganic pollutants. The content of heavy metals is higher in the area of the rolling stock cleaning bay and the railroad siding, while the areas of goods handling station and the platform were less contaminated. The study found high contents of iron, cobalt, zinc and chromium in samples collected from the rolling stock cleaning bay and high contents of $\mathrm{Cu}, \mathrm{Mn}$ and $\mathrm{Zn}$ at different parts of the railroad junctions. Comparing the scientists' data with the results from Zduńska Wola, it should be stated that the content of the mentioned elements was also at the highest level, with particular emphasis on Mn.

\section{Conclusion}

The high level of heavy metal contamination of soils in railroad areas can have a destabilizing effect on ecosystems. The study found that the $\mathrm{pH}$ values of investigated soils ranged from 6.47 (slightly acidic) to 7.29 (slightly alkaline). With increasing distance from the rails, the $\mathrm{pH}$ value decreased. The average concentrations of particular metals in the soil of railroad junction in Zduńska Wola were as follows: $\mathrm{Mn}>\mathrm{Cu}>\mathrm{Zn}>\mathrm{Sr}>\mathrm{Pb}>\mathrm{Ni}>\mathrm{Cr}>\mathrm{Co}>\mathrm{Cd}$. Higher trace metal contents were found in the very fine sand fraction $(0.05 \leq 0.1 \mathrm{~mm})$. The highest concentrations of heavy metals were recorded in samples collected from close to the rails (inter-railway, side track), and in the embankment (10 $\mathrm{m}$ from the track). The mean values of accumulation index in the investigated soils were arranged in the following series $\mathrm{Cu}>\mathrm{Cd}>\mathrm{Pb}>\mathrm{Zn}>\mathrm{Mn}>\mathrm{Ni}>\mathrm{Co}>\mathrm{Cr}$. The high accumulation index of copper, cadmium and lead in the surface layer of soil indicate their anthropogenic origin.

Conflicts of Interest: The authors declare no conflict of interest.

\section{References}

1. Adamiec E, Jarosz-Krzemińska E, Wieszała R (2016) Heavy metals from non-exhaust vehicle emissions in urban and motorway road dusts. Environ. Monit. Assess. 188, 369.

2. Antuniassi UR, Velini ED, Nogueira HC (2004) Soil and weed survey for spatially variable herbicide application on railways. Precision Agriculture 5:27 - 39 .

3. Bai J, Cui B, Wang Q, Gao H, Ding Q (2009) Assessment of heavy metal contamination of roadside soils in Southwest China. Stoch Environ Res Risk Assess 23:341-347.

4. Bednarek R, Dziadowiec H, Pokojska U, Prusinkiewicz Z (2004) Badania ekologiczno - gleboznawcze. Wydawnictwo Naukowe PWN, Warszawa.

5. Bukowiecki N, Gehrig R, Hill M, Lienemann B, Zwicky CN, Buchmann B (2007) Iron, manganese and copper emitted by cargo and passenger trains in Zuric (Switzerland): Size- segregated mass concentrations in ambient Air, Atmospheric Environment 41:878-889.

6. Chen Z, Wang K, Ai YW, Li W, Gao H, Fang C (2014) The effects of railway transportation on the enrichment of heavy metals in the artificial soil on railway cut slopes. Environmental Monitoring and Assessment 186(2): 1039-1049. doi:10.1007/s10661-013-3437-3

7. Chillrud SN, Grass D, Ross JM, Couliblay D, Slavkovich V, Epstein D, Sax SN, Pederson D, Johnson D, Spengler JD, Kinney PL, Simpson J, Brandt-Rauf P (2005) Steel Dust in the New York City Subway System as a Source of Manganese, Chromium, and Iron Exposures for Transit Workers. Journal of Urban Health: Bulletin of the New York Academy of Medicine 82, 1: 33-42. 
8. Czarnowska K (1996) Ogólna zawartość metali ciężkich w skałach macierzystych jako tło geochemiczne gleb. Roczniki Gleboznawcze, T. XLVII, Warszawa, 43 - 50.

9. Duong TTT, Lee BK (2011) Determining contamination level of heavy metals in road dust from busy traffic areas with different characteristics. J. Environ. Manag 92: 554-562.

10. Gehrig R, Hill M, Lienemann P, Zwicky CN, Bukowiecki N, Weingartner E (2007) Contribution of railway traffic to local PM10 concentrations in Switzerland. Atmospheric Environment 41:923-933.

11. Greinert H, Greinert A (1999) Ochrona i rekultywacja środowiska glebowego. Wydawnictwo Politechniki Zielonogórskiej, Zielona Góra.

12. Jóźwiak M, Jóźwiak MA, Fałtynowicz W, Kozłowski R (2013) Możliwości wykorzystania porostów do oceny zanieczyszczenia terenów kolejowych - założenia metodyczne, wstępne wyniki. Monitoring Środowiska Przyrodniczego 14: 45-53.

13. Kabata-Pendias A, Pendias H (1999) Biogeochemistry of trace elements (in Polish). PWN, Warszawa

14. Krailertrattanachai N, Ketrot D, Wisawapipat W (2019) The Distribution of Trace Metals in Roadside Agricultural Soils, Thailand. Int. J. Environ. Res. Public Health 16: 714; doi:10.3390/ijerph16050714.

15. Li F, Fan Z, Xiao P, Oh K, Ma X, Hou W (2009) Contamination, chemical speciation and vertical distribution of heavy metals in soils of an old and large industrial zone in Northeast China. Environmental Geology 57:1815-1823.

16. Liu H., Chen LP, Ai YW, Yang X, Yu YH, Zuo YB (2009) Heavy metal contamination in soil alongside mountain railway in Sichuan, China. Environmental Monitoring Assessment 152:25-33.

17. Lucas PS, de Carvalho RG, Grilo C (2017) Railway Disturbances on Wildlife: Types, Effects, and Mitigation Measures. Railway Ecology 81-99. doi:10.1007/978-3-319-57496-7_6

18. Łukasiewicz Sz (2011) Struktura fizyczna gruntu, zawartość substancji organicznej oraz skład chemiczny gleb w podłożach 21 stanowisk zieleni miejskiej na terenie Poznania, Badania Fizjograficzne, R. III - Seria A - Geografia fizyczna, 49 - 75, DOI 10.2478/v10116-012-0002-7.

19. Malawska M, Wiłkomirski B (2000) Soil and plant contamination with heavy metals in the area of old railway junction Tarnowskie Góry and near two main railway routes, ROCZNIKI PZH. 51:259 - 267.

20. Malawska M, Wiłkomirski B (2001) An analysis of soil and plant (Taraxacum officinale) contamination with heavy metals and polycyclic aromatic hydrocarbons (PAHs) in the area of railway junction Iława Główna, Poland. Water, Air, and Soil Pollution 127: 339-349.

21. Moczarski M (2006) Obsługiwanie pojazdów szynowych a zagrożenie środowiska. Problemy Kolejnictwa, Z.143:59-86.

22. Rapalska M (2010) Analiza zawartości metali ciężkich w glebach Tatrzańskiego Parku Narodowego w części słowackiej (TANAP), V Krakowska Konferencja Młodych Uczonych, Kraków, 327 - 335.

23. Samarska A, Zelenko Y, Kovrov O (2020) Investigation of Heavy Metal Sources on Railways: Ballast Layer and Herbicides. Journal of Ecological Engineering 21, 8:32-46.

24. Stojic N, Pucarevic M, Stojic G (2017) Railway transportation as a source of soil pollution. Transportation Research Part D: Transport and Environment 57:124-129. doi:10.1016/j.trd.2017.09.024

25. Šeda M, Ším J, Volavka T, Vondruška J (2017) Contamination of soils with $\mathrm{Cu}, \mathrm{Na}$ and $\mathrm{Hg}$ due to the highway and railway transport. Eurasian Journal of Soil Science 6(1):59-64. https://doi.org/10.18393/ejss.284266

26. Vaiškūnaitė R, Jasiūnienè V (2020) The analysis of heavy metal pollutants emitted by railway transport. Transport 35(2):213-223. https://doi.org/10.3846/transport.2020.12751

27. Wierzbicka M, Bemowska-Kałabun O, Gworek B (2015) Multidimensional evaluation of soil pollution from railway tracks. Ecotoxicology 24(4):805-822. doi:10.1007/s10646-015-1426-8

28. Wiłkomirski B (2010) Stoi na stacji lokomotywa, czyli zanieczyszczenia środowiska związane z transportem kolejowym. Rocznik Świętokrzyski. Ser. B - Nauki Przyr. 31:85-94.

29. Wiłkomirski B, Galera H, Sudnik-Wójcikowska B, Staszewski T, Malawska M (2012) Railway tracks habitat conditions, contamination, floristic settlement - a review. Environment and Natural Resources Research 2, 1:86-95.

30. Wiłkomirski B, Sudnik-Wójcikowska B, Galera H, Wierzbicka M, Malawska M (2011) Railway transportation as a serious source of organic and inorganic pollution. WATER, AIR and SOIL POLLUTION 218: 333-345.

31. Yan X, Zhang F, Zeng C, Zhang M, Devkota LP, Yao T (2012) Relationship between heavy metal concentrations in soils and grasses of roadside farmland in Nepal. Int. J. Environ. Res. Public Health 9:3209-3226.

32. Zhang H, Wang ZF, Zhang YL, Hu ZJ (2012) The effects of the Qinghai-Tibet railway on heavy metals enrichment in soils. Science of the Total Environment 439:240-248. 
33. Zhang H, Wang Z, Zhang Y, Ding M, Li L (2015) Identification of traffic-related metals and the effects of different environments on their enrichment in roadside soils along the Qinghai-Tibet highway. Sci. Total Environ 521-522, 160-172. 